\title{
Parenting Module for Parents of Children with Mental Retardation to Improve Understanding in Parenting
}

\section{Aulia Nailul Muna ${ }^{1 *}$, Sunardi ${ }^{2}$, Herry Widyastono ${ }^{3}$}

1,2,3 Postgraduate of Special Education, Universitas Sebelas Maret, Surakarta, Indonesia

*e-mail: auliya martini@yahoo.com

\begin{abstract}
This study aims to produce media in the form of parenting modules for parents of children with mental retardation that suitable to be used by the parents. Some things that are important in this study include increasing the knowledge and understanding of parents of children with mental retardation so that they can care for the children according to their abilities. In addition, they can develop optimally, and solve problems faced by parents of children with mental retardation. It provides solutions toward the parents' problems so that children with mental retardation can grow and develop properly. This study uses Research and Development (R\&D) based on Borg and Gall. The conducted stages include research and data collection, planning, product draft development, product testing, and revision of product trial results. This product was tested on 21 parents of children with mental retardation. The feasibility of the product is based on the evaluation results of material experts, media experts, and parents of students as test subjects. Data collection techniques used observation, interviews, questionnaires, and documentation. Data analysis at the problem identification stage used descriptive analysis. While the data analysis technique used on product quality is quantitative descriptive data analysis. The results showed that the parenting module media for parents of children with mental retardation was developed through a series of trials, and expert validation was declared feasible.
\end{abstract}

Keywords: Understanding, Parenting, Mental Retardation

\section{Introduction}

Children are a precious gift for every family and every parent certainly expects the presence of children who are physically and spiritually healthy (Damanik \& Sinaga, 2021; Mustika Sari et al., 2018). However, not every child born to grow and develop in accordance with the expected. One of the children with special needs is called children with mental retardation. Children with mental retardation are defined as children with condition of mental development are not perfect or stalled characterized by social behavior, language and adaptive skills. Children with mental retardation have intellectual abilities below the average accompanied by limited adaptive functions (Cluley, 2018; Nugraha, 2017; Sutinah \& Saswati, 2017). Then, according to the Guidelines for Classifying the Diagnosis of Mental Disorders, mental retardation is a state of mental development that is stopped or incomplete, which is mainly characterized by the occurrence of skill barriers during the developmental period (Hadjimina \& Furnham, 2017; Sari, Binahayati, 2017; Sutinah \& Nofrodra Saswati, 2017).

Furthermore, the American Association on Mental Deficiency defines mental retardation as a disorder whose intellectual function is generally below average that is IQ of 84 and below. (Mayasari, 2019). Usually children with mental retardation will have difficulty in "Adaptive Behavior" or behavior adjustment (Winarsih et al., 2013). Parents who have children with mental retardation often experience problems in their care as the condition of children with mental retardation who have very limited intellectual functions and adaptive behavior abilities. Parents of children with mental retardation experience stages of psychological conditions such as shock, rejection, guilt, anger, frustration and depression (Hadjimina \& Furnham, 2017; Jalali et al., 2016). Several studies have shown that parents of children with mental retardation show feelings of sadness, depression, anger and lack of acceptance of their child's condition (Dogar et al., 2011, 2013). They feel that their children

\footnotetext{
${ }^{*}$ Corresponding author.

Received January 11, 2021; Accepted June 20, 2021; Available online December 25, 2021

This is an open access article under the CC BY-SA license. Copyright ( 2021 by Author. Published by Universitas Pendidikan Ganesha
} 
are not developing like other children at their age, parents are worried about their children's future and the stigma attached to their children. Various problems experienced by parents who have children with mental retardation (Sutinah \& Saswati, 2017; Tri Na'imah, Nur 'Aini, 2017). Then the results of future studies addressing that parent of children with mental retardation suffer from stress are quite severe and they often do not have the means to cope with children with mental retardation. The results of further research found that parents of children with mental retardation have higher anxiety level (Akturk, 2017; Priyadarshee Patra, Jyoti Prakash, 2016).

Parents who have children with mental retardation often experience emotional and personal burdens in caring for children with mental retardation (Hastings, 2017; Luijkx et al., 2019; Upendra et al., 2020; Verma et al., 2016). In caring for children with mental retardation in general, there will be difficulties faced by parents and it seems that their are confused because their child does not develop properly, parents also find it difficult to find information about their child's condition (Maysa\&khairiyah, 2019). Every child, whoever they are, regardless of their circumstances, have the same rights to get love from parents and get the same education according to their conditions and abilities (Siregar, 2013). Parenting children with mental retardation is different to parenting general children that do not have barriers. Children with mental retardation take significant time, attention and self-care education (Bourke-Taylor et al., 2021; Dogar et al., 2011, 2013). Therefore, the role of parents is very important and very much needed in caring for children with mental retardation. Caring for children with mental retardation must be based on love so that children can develop good social behavior. On the other hand, if there is a lack of supervision/attention from parents, it will have a bad impact on the development of children with mental retardation (Goryacheva \& Sinelnikova, 2014; Silitonga, 2019). Parents should have an understanding of children with mental retardation such as the definition of children with mental retardation, classification of children with mental retardation, characteristics of children with mental retardation, strategies for parenting children with mental retardation, and self-development of children with mental retardation (Goryacheva \& Sinelnikova, 2014; Hadjimina \& Furnham, 2017). It is conducted as an effort to overcome the difficulties and obstacles of parents in caring for children with mental retardation and can also reduce the stress and confusion of parents in dealing with the children.

However, at this time there are parents who do not understand in caring for children with mental retardation. This is shown by interviews with 10 parents in Kendal district who stated that parents of children with mental retardation expect their children to recover and can be like other normal children. It shows that parents of retarded children do not have an understanding of mental retardation because mental retardation is a condition that can not be cured with medication (Widiastuti, 2019). And not a few parents who have children with mental retardation do not know what is needed in developing the development of children with mental retardation such as communicating, taking care of themselves, socializing, skills in maintaining health and safety, and practicing to work to become a preparation for the life to come (Istafia et al., 2020; Kosasih, 2017). Parents feel pessimistic and consider themselves as parents who cannot care for children with mental retardation and they only expect their children to be physically healthy and do not expect their children to develop their abilities or behave independently to get special achievements (Apriliyanti et al., 2017; Sutinah \& Saswati, 2017). Parents find it difficult to take care of children with mental retardation. Then the research conducted by Hadi Kosasih and Stefani Virlia showed that the majority of the research respondents had a low acceptance rate or in other words they had not accepted the mental retardation condition in their child (48\%) (Kosasih, 2017).

This shows that parents do not know how to take care of children with mental retardation, and need references to increase knowledge in caring for children with mental retardation. Then further research showed that parents feel sad having children with mental retardation, then parents feel upset toward children with mental retardation if the child could not quickly do what have been taught about performing daily activities even though it is repeated (Anggraeni et al., 2018). Furthermore, another study found that some parents feel sad and worried about their mentally retarded children and limit their interactions with 
neighbors for fear of mental disorders and humiliation (Apriliyanti et al., 2017). This shows that parents of mentally retarded children need references to improve understanding of mentally retarded children and increase knowledge in caring for mentally retarded children, so that parents do not feel stressed and mentally retarded children are handled properly and can develop as expected. their abilities. Understanding is the result of learning (Lan et al., 2010; Subagyo, 2017). Understanding is the ability to capture the meaning and purpose of things being studied. (Kusmawati, 2016; Smith et al., 2018). Then someone can be said to understand if they can construct meaning from learning messages, either verbally, in writing or graphically, delivered through teaching, books (Moll-Khosrawi et al., 2021; Muh Syihab Ikbal, Nurhayati, 2018; Nursyahidah et al., 2013). Understanding is a person's ability to understand or understand something after something is known and remembered. In other words, understanding is knowing about something and being able to see it from various angles.

Parents of children with mental retardation are said to understand to take care of children with mental retardation if the parents can provide care according to the condition of the child. Understanding is defined as the ability to capture the meaning of something (Fitriyane Laila Apriliani Rahmat, Suwatno, 2018; Yonanda, 2017). From some of the explanations above, this research aims to provide an understanding of parenting children with mental retardation for parents who have children with mental retardation which produces products in the form of parenting modules for parents so that they can use it to increase the knowledge and understanding of parents in caring for children with mental retardation. Researchers hope that parents who have children with mental retardation can improve their knowledge and skills in caring for children with mental retardation so that the children can grow and develop according to their conditions and abilities.

\section{Method}

This research used research and development approach, which is a process used to develop and validate the product to be developed. The researchers conducted a field survey by using observation, interviews and filling out questionnaires about understanding parenting for parents of children with mental retardation as an initial stage to obtain potential data and problems in the field, then designing the product to be produced. In this study there are several possibilities if the results of this research product are applied to parents who have mental disorders or retarded children. The development of the parenting module for parents of children with mental retardation refers to the development research steps according to Borg and Gall (Sugiono, 2010). The subjects in this study were parents of children with mental retardation.

The first research stage is to analyze the potential and problems regarding parenting for parents of children with mental retardation. The purpose of the potential and problem stage is to analyze the needs and identify the level of understanding of parents in caring for children with mental retardation. The method used is filling out questionnaires, interviews, and observations. The second stage is data collection, compiled after problems are found, then collect information that can be used as material for designing product preparation. Then the third stage is product design that is developing a draft of a parenting module for parents of children with mental retardation, while the steps are summarizing the results of a literature study, making a module framework. The fourth stage is design validation, which is to assess whether the product is suitable for use, product validation is conducted by involving several experts so that the advantages and disadvantages of the product can be known. Then the fifth stage is design revision, the design revision is conducted after the product is validated so that the disadvantages of the product can be identified. From these disadvantages, researchers will make revisions to repair the product disadvantages. After getting an assessment from the validator and the results are analyzed, product development is complete. The next stage is a limited-scale initial trial, after revision, the module will be tested on a small group of parents in special schools. 


\section{Result and Discussion}

\section{Results}

The result of this development research is the development of a parenting module for parents of children with mental retardation to increase understanding in parenting for parents of children with mental retardation at SLB N Kendal and SLB Swadaya Kendal. Based on the results of filling out questionnaires that have been conducted on parents of children with mental retardation at the potential and problem stage at SLB N Kendal and SLB Swadaya Kendal regarding understanding in parenting children, the calculation of the answer "Yes" from the questionnaire questionnaire, which the averag answer obtained is $16 / 4 \times 100 \%=$ $40 \%$. From the Guttman scale analysis, the point of conformity is below $50 \%$, which is $40 \%$, it is said that the understanding of parents regarding parenting children with mental retardation is still low. In conclusion, the understanding of parents in raising children is still lacking / inappropriate, with a percentage of $40 \%$.

Based on the results of interviews conducted with ten parents of children with mental retardation during a preliminary study at SLB N and SLB ABC Swadaya Kendal, it was found that; Parents of children with mental retardation do not understand about mental retardation. They understand that their children are different from normal children their age. Parents of children with mental retardation find it difficult and confused about how to take care of children with mental retardation because children with mental retardation take very long to respond and are not easy to catch when taught something. Parents find it difficult to teach children with mental retardation because children with mental retardation are very slow and get bored easily. Then, parents get difficulties to find how to teach children with mental retardation to understand what is being taught. They consider children with mental retardation to be sick. Parents often take their children with mental retardation to alternative medicine and ask for prayer from religious leaders hoping their children can be normal like normal children at their age. All parents stated that they needed their insight and knowledge related to caring for children with mental retardation according to the potential that could be developed. So far, the parents had never followed or educated themselves to care for children with mental retardation. All parents thought and hped that there would be a program from the school to provide training on how to raise children.

Based on the results of observations and documentation that have been conducted at SLB N Kendal and SLB Swadaya related to caring for children with mental retardation, the following facts were found: Activities conducted by parents of children with mental retardation are teaching how to write and count with their fingers. The way parents provide learning like children in general, by looking at the condition of children with mental retardation who are easily bored parents should use media or learning tools that support so that children with mental retardation are interested and passion for doing it. After the potential and problem stages, collecting data and processing is conducted to support the development of the module. Sources or references for the development of teaching materials are obtained from relevant sources. After analyzing the needs, the next step is product design. There are several things that are conducted in the product design stage of the development of parenting training modules for parents of children with mental retardation in parenting materials. The steps for preparing the product design of this teaching material are including adjusting.

Product validation of the development of parenting training modules for parents of children with mental retardation was validated by 5 experts, consisting of 2 material and presentation experts, 1 linguist, 1 graphic expert. The criteria in determining the subject of an expert are: experienced in the field, has minimum education of graduate programme. The used instrument refers to the regulation of the Minister of Education and Culture of the Republic of Indonesia No. 8 of 2016 concerning books used by education units (Kemendikbud, 2016). Based on the results of data analysis, the average validation result given by the experts is getting a score of $95 \%$ so that it is included in the Very Eligible Evaluation category. The average rating given by practitioners is $86.6 \%$ so that it is included in the Very Eligible Evaluation category. After the product design was validated through 
material experts, material presentation experts, linguists and graphic experts, the research revised the developed product design.

In the trial of using the product for the purpose of attracting the product, parents of children with mental retardation see the product (parenting module for parents of children with mental retardation). Product trial involving 20 parents of children with mental retardation at SLB N Kendal and SLB ABC Kendal. Parents of children with mental retardation are given a module that has gone through the revision stage and then given a module assessment instrument. The results of the parent's response to the developed module obtained results with an average of 84.9 this percentage was included in the very feasible category. This means that the developed module has interesting criteria to be used as a medium to increase the understanding of parents in caring for children with mental retardation. Based on the results of field tests on a limited scale that have been conducted on twenty parents of children with mental retardation at SLB N Kendal and SLB ABC Swadaya Kendal results obtained that the product developed has a rating of $96.25 ; 97.5 ; 98.75 ; 95 ; 76.25 ; 76.25 ; 90$; $90 ; 70 ; 75 ; 75 ; 78.75 ; 75 ; 87.5 ; 82.5 ; 82.5 ; 82.5 ; 96.25 ; 98,75$; and 75 . The results of the product assessment developed in field test on a limited scale on parents of children with mental retardation generally have an average score of 84.9 and have very decent qualifications. This means that the developed module has the feasibility to be used as a medium to increase the understanding of parents in caring for children with mental retardation. Then this stage is the last stage in the procedure for developing parenting training modules for parents of children with mental retardation.

\section{Discussion}

This research was conducted to produce a product in the form of a Parenting module for parents of children with mental retardation. This printed module is arranged according to conditions in the field, in this module there is a description of the material that aims to provide knowledge about children with mental retardation. After reading the description of the material, parents of children with mental retardation fill out practice questions to determine the level of knowledge obtained. Then there is an assessment to determine the score whether the material can be continued or repeated. In accordance with Bloom's opinion that knowledge is a basic level at this level which emphasizes the ability to recall the material that has been learned. Then there are assignments that aim to apply the knowledge that has been obtained and the task assessment rubric as a reference for parents about the level of ability of children with mental retardation. Developed module also features drawings, illustrations, and language that is easily understandable in order to increase reader's interest and motivation (Hairida, 2016; Handayani et al., 2021; Ningsih \& Mahyuddin, 2021).

Printed teaching materials are better than other types of teaching materials (Agustina, 2018; Mastroleo et al., 2020; Matsun et al., 2019). Besides being able to present a variety of contents, the module can be used as reference material. The product developed in this research is a module that contains the understanding of children with mental retardation, caring for children with mental retardation and self-development of children with mental retardation accompanied by supporting pictures. One of the functions of visual media is that the visual function is a cognitive function (Alfiyani, 2018; Sapriyah, 2019). Cognitive function in visual media can be seen from research findings which reveal that visual symbols or images facilitate the achievement of goals to understand and remember information or messages contained in images (Agung et al., 2017; Gever et al., 2021). This is in accordance with the developed module, which not only presents material in the form of writing but is also accompanied by two dimensional images as examples.

The advantages of print media are as follows: it can be read many times, if it is stored, it makes someone think more specifically about the content of the writing, it can be collected, the price is quite affordable and it is able to explain complex things better (Puspitasari, 2019; Sedana, 2020; Westomi et al., 2018). In addition, the functions or roles of the print media include as information media that can enlighten, as educational media that can educate, improve intellectual life in society, and assist or encourage in strengthening national unity. (Amini \& Suyadi, 2020; Apriliani \& Radia, 2020; Kuswanto \& Walusfa, 2017). 
Based on the results of the data in the first stage, the average answer was obtained by $40 \%$. From the Guttman scale analysis, the point of conformity is below $50 \%$ which is $40 \%$. It is said that the understanding of parents regarding parenting of children with mental retardation is still low. In conclusion, the understanding of parents in raising children is still lacking/ inappropriate based on the percentage of $40 \%$. In addition, the results of interviews and observations showed that most parents of children with mental retardation do not have the knowledge and understanding in caring for children with mental retardation.

The module developed by the researcher has gone through several stages including the preliminary study stage, which is the collection of potential data and problems so that a model, system or pattern of handling can be found that can help overcome problems and provide solutions to the difficulties faced by parents of children with mental retardation. Parenting module for parents of children with mental retardation contains the understanding of mental retardation, classification and characteristics of children with mental retardation, strategies for parenting children with mental retardation, and self-development of children with mental retardation. Therefore, the parents obtain explanations, knowledge, and understanding in caring for children with mental retardation (Cluley et al., 2020; Mayasari, 2019). With the parenting module for the parents that will be used by them, it is expected that parents gain knowledge and understanding in caring for children with mental retardation in accordance with the conditions and can develop the abilities that exist in the children. There is an advantage in this study in the form of products that are produced and are worthy of being used as reference materials in caring for children with mental retardation. In addition, it can provide solutions and help solve problems faced by the parents. The obtained results found that whether getting a positive assessment of a single mother in the form of pride and negative assessment because of the shame on the child's condition, the mother hope that the child is able to live independently and live a life like normal people in the future (Cluley, 2018; Rahmadani, 2019; Tri Na'imah, Nur 'Aini, 2017).

After parents read the parenting module for parents of children with mental retardation, parents get knowledge. After gaining knowledge about caring for children with mental retardation, parents can understand children with mental retardation where understanding is defined as the ability to understand the material being studied (Dogar et al., 2013; Istafia et al., 2020; Kosasih, 2017). At this level, parents can provide examples of both principles and concepts. Operational verbs that can be used at this level are: estimate, explain, categorize, detail, change, explore, pattern, summarize, and describe. It is hoped that after gaining knowledge, parents can understand children with mental retardation so that they can explain, estimate, and give pattern on how to care for children with mental retardation according to their conditions and optimize the abilities of children with mental retardation. From the explanation above, it is expected that the module parenting for parents of children with mental retardation can increase their knowledge, understanding in caring for children with mental retardation, and provide solutions to the problems faced by parents in caring for children retarded. Therefore, children with mental retardation will get better care which is in accordance with their conditions and be able to grow well. In this development research, there are still limitations. It is expected to conduct further research by taking a wider sample, more sample, and using a more complex research design. For the readers, it is hoped that they can add insight into knowledge about children with mental retardation.

\section{Conclusions and Suggestions}

The developed product is suitable to be used to help parents who have children with mental retardation, besides the module on parenting for parents of children with mental retardation as an independent alternative teaching material for parents of children with mental retardation. 


\section{References}

Agung, A. A. G., Widiana, I. W., \& Indrasuari, N. K. S. (2017). Pengembangan Aktivitas Pembelajaran Mengasosiasi Berbasis Media Gambar Berseri Dalam Meningkatkan Proses Kognitif Siswa. Jurnal Ilmiah Sekolah Dasar, 1(3), 138. https://doi.org/10.23887/jisd.v1i3.10323.

Agustina, A. (2018). Menerapkan Penggunaan Bahan Ajar Bagi Guru Di SMA Negeri 3 Ogan Komering Ulu. Journal Of Educational Studies, 3(1), 16-29. https://doi.org/http://dx.doi.org/10.30983/educative.v3i1.563.

Akturk, U. R. A. (2017). An Evaluation of Anxiety in Parents with Disabled Children and their Coping Strategies. International Journal of Caring Sciences, 10(1), 342-353.

Amini, N., \& Suyadi, S. (2020). Media Kartu Kata Bergambar Dalam Meningkatkan Kemampuan Kosakata Anak Usia Dini. PAUDIA: Jurnal Penelitian Dalam Bidang Pendidikan Anak Usia Dini, 9(2), 119-129. https://doi.org/10.26877/paudia.v9i2.6702.

Anggraeni, L. D., Gaol, E. L., \& Carolus, S. S. (2018). Pengalaman Orang Tua Dalam Memandirikan Anak Dengan Tunagrahita. Jurnal IImu Keperawatan Dan Kebidanan., Vol 10(2). http://ejournal.stikestelogorejo.ac.id/index.php/jikk/article/view/738.

Apriliani, S. P., \& Radia, E. H. (2020). Pengembangan Media Pembelajaran Buku Cerita Bergambar Untuk Meningkatkan Minat Membaca Siswa Sekolah Dasar. Jurnal Basicedu, 4(4), 994-1003. https://doi.org/10.31004/basicedu.v4i4.492.

Apriliyanti, D., Anugrahni, D., \& Agustina, V. (2017). Hubungan Kemampuan Manajemen Stres Dengan Tingkat Stres Pada Orangtua Anak Tunagrahita di SLBN 1 Palangkaraya. Jurnal Kesehatan Masyarakat, 4(2), 43-46. https://doi.org/http://dx.doi.org/10.31602/ann.v4i2.1164.

Arsyad, A. (2014). Pengembangan Bahan Ajar. PT. Grafindo Persada.

Bourke-Taylor, H. M., Joyce, K. S., Grzegorczyn, S., \& Tirlea, L. (2021). Mental Health and Health Behaviour Changes for Mothers of Children with a Disability: Effectiveness of a Health and Wellbeing Workshop. Journal of Autism and Developmental Disorders, 0123456789. https://doi.org/10.1007/s10803-021-04956-3.

Cluley, V. (2018). From "Learning disability to intellectual disability"-Perceptions of the increasing use of the term "intellectual disability" in learning disability policy, research and practice. British Journal of Learning Disabilities, 46(1). https://doi.org/10.1111/bld.12209.

Cluley, V., Fyson, R., \& Pilnick, A. (2020). Theorising disability: a practical and representative ontology of learning disability. Disability and Society, 35(2). https://doi.org/10.1080/09687599.2019.1632692.

Damanik, R., \& Sinaga, W. (2021). The Values of Character in Traditional Games Simalungun Society. Budapest International Research and Critics Institute (BIRCIJournal): Humanities and Social Sciences, 4(1), 1059-1069. https://doi.org/10.33258/birci.v4i1.1713.

Dogar, I. A., Azeem, M. W., Haider, I., Wudarsky, M., \& Asmat, A. (2011). Well being and psychiatric status of parents of children with Mental Retardation in Pakistan. European Psychiatry, 26(1). https://doi.org/10.1016/S0924-9338(11)71988-5.

Dogar, I. A., Azeem, M. W., Shah, S., Cheema, M. A., \& Asmat, A. (2013). Anxiety and depression among parents of children with mental retardation. European Psychiatry, 28. https://doi.org/10.1016/S0924-9338(13)77482-0.

Fauzan Alfiyani, Tri Kurniawati, M. K. (2018). Pengembangan Webtoon Untuk Pembelajaran IPS (Ekonomi) Di SMP. Jurnal EcoGen, Vol 1 No 2, 439-449. https://doi.org/http://dx.doi.org/10.24036/jmpe.v1i2.4766.

Fitriyane Laila Apriliani Rahmat, Suwatno, R. (2018). Meningkatakan Pemahaman Konsep Siswa Melalui Teams Games Tournament (TGT): Meta Analysis. Jurnal Manajemen Dan Sistem Informasi, 3(5), 239-246.

Gever, V. C., Tunca, E. A., Boluwatife, A. A., Nwogbo, V. C., \& Chinweobo-Onuoha, B. N. (2021). Visual media and learning: Effect of interactive television instruction as an intervention strategy for improving the critical thinking skills and disposition of out-of- 
school nomadic children in Nigeria. Learning and Motivation, 76. https://doi.org/10.1016/j.Imot.2021.101767.

Goryacheva, T., \& Sinelnikova, A. (2014). Child-parent relationship as a factor in maturing of empathy in children with mental retardation. European Psychiatry, 9(1). https://doi.org/10.1016/S0924-9338(14)77928-3.

Hadjimina, E., \& Furnham, A. (2017). Influence of age and gender on mental health literacy of anxiety disorders. Psychiatry Research, 251, 8-13. https://doi.org/10.1016/j.psychres.2017.01.089.

Hairida, H. (2016). The effectiveness using inquiry based natural science module with authentic assessment to improve the critical thinking and inquiry skills of junior high school students. Jurnal Pendidikan IPA Indonesia, 5(2), 209-215. https://doi.org/10.15294/jpii.v5i2.7681.

Handayani, D., Elvinawati, E., Isnaeni, I., \& Alperi, M. (2021). Development Of Guided Discovery Based Electronic Module For Chemical Lessons In Redox Reaction Materials. International Journal of Interactive Mobile Technologies (IJIM), 15(07), 94. https://doi.org/10.3991/ijim.v15i07.21559.

Hastings, R. P. (2017). Do Children With Intellectual and Developmental Disabilities Have a Negative Impact on Other Family Members? The Case for Rejecting a Negative Narrative. International Review of Research in Developmental Disabilities, 50, 165194. https://doi.org/10.1016/bs.irrdd.2016.05.002.

Istafia, Rohmi, F., \& Aditya, R. S. (2020). Tingkat Stress Orangtua Mempengaruhi Perilaku Adaptif Anak Tingkat Stress Orangtua Mempengaruhi Perilaku Adaptif Anak Retardasi Mental Di Slb-BC Kepanjen Kab Malang. Jurnal Keperawatan Terapan, March. https://doi.org/10.31290/jkt.v6i01.1460.

Jalali, L. C., Hasanzadeh, S., Davaee, M., \& Afrooz, G. (2016). Development and assessment of effects of de-stress training program on stress of mothers with mentally disabled children. Iranian Rehabilitation Journal, 14(4), 223-228. https://doi.org/10.18869/nrip.irj.14.4.223.

Kemendikbud. (2016). Peraturan Menteri Pendidikan Dan Kebudayaan Republik Indonesia Nomor 8 Tahun 2016 Tentang Buku Yang Digunakan Oleh Satuan Pendidikan. Kementerian Pendidikan dan Kebudayaan.

Kosasih, H. (2017). Gambaran Penerimaan Orang Tua Dengan Anak Retardasi Mental Di Sekolah Luar Biasa (Slb) C "Dg" Dan Slb C "Sj." Psibernetika, 9(1), 27-36. https://doi.org/10.30813/psibernetika.v9i1.475.

Kusmawati, G. G. S. L. (2016). Peningkatan Kemampuan Pemahaman Konsep Perkalian Melalui Pendekatan Pembelajaran Konstruktivisme Pembelajaran Matematika Di Kelas 3 SDN Cibaduyut 4. Didaktik: Jurnal IImiah PGSD STkIP Subang, Vol 1 No 2, 262-671. https://doi.org/https://doi.org/10.36989/didaktik.v1i2.32.

Kuswanto, J., \& Walusfa, Y. (2017). Pengembangan Multimedia Pembelajaran pada Mata Pelajaran Teknologi Informasi dan Komunikasi Kelas VIII. Innovative Journal of Curriculum and Educational Technology IJCET, 6(2), 58-64. https://doi.org/10.15294/ijcet.v6i2.19335.

Lan, K. L., Abdullah, M. C., \& Roslan, S. (2010). Understanding media violence and the development of aggressive behaviour of school children. Procedia - Social and Behavioral Sciences, 7(2), 522-527. https://doi.org/10.1016/j.sbspro.2010.10.070.

Luijkx, J., van der Putten, A. A. J., \& Vlaskamp, C. (2019). A valuable burden? The impact of children with profound intellectual and multiple disabilities on family life. Journal of Intellectual and Developmental Disability, 44(2), 184-189. https://doi.org/10.3109/13668250.2017.1326588.

Mastroleo, N. R., Humm, L., Williams, C. M., \& Kiluk, B. D. (2020). Initial testing of a computer-based simulation training module to support clinicians' acquisition of CBT skills for substance use disorder treatment. Journal of Substance Abuse Treatment, 114. https://doi.org/10.1016/j.jsat.2020.108014.

Matsun, Andrini, V. S., Maduretno, T. W., \& Yusro, A. C. (2019). Development of physics learning e-module based on local culture wisdom in Pontianak,West Kalimantan. 
Journal of Physics: Conference Series, 1381(1). https://doi.org/10.1088/17426596/1381/1/012045.

Mayasari, N. (2019). Layanan Pendidikan Bagi Anak Tunagrahita Dengan Tipe Down Syndrome. Yinyang: Jurnal Studi Islam Gender Dan Anak, 14(1), 111-134. https://doi.org/10.24090/yinyang.v14i1.2847.

Moll-Khosrawi, P., Cronje, J. S., Zöllner, C., Kubitz, J. C., \& Schulte-Uentrop, L. (2021). Understanding How the Motivational Dimension of Learning is Influenced by Clinical Teaching in Medical Education: A Prospective Cohort Study. Annals of Medicine and Surgery, 65(February), 1-7. https://doi.org/10.1016/j.amsu.2021.102366.

Muh Syihab Ikbal, Nurhayati, Y. A. (2018). Pengaruh Metode Guided Inquiry Dan Pengetahuan Operasi Dasar Matematika Dalam Praktikum Fisika Dasar Terhadap Pemahaman Konsep Fisika Mahasiswa Pendidikan Fisika UIN Alauddin Makassar. Al -Ta'dib Jurnal Kajian IImu Kependidikan, 11(1), 19-36. https://doi.org/http://dx.doi.org/10.31332/atdb.v11i1.943.

Mustika Sari, I. T., Toha, H., \& Nurani, Y. (2018). Improving Early Childhood Prosocial Behavior through Activity Storytelling with Puppets. Jurnal Obsesi : Jurnal Pendidikan Anak Usia Dini, 2(2), 155. https://doi.org/10.31004/obsesi.v2i2.75.

Ni Luh Gede Karang Widiastuti, I. M. A. W. (2019). Prinsip Khusus Dan Jenis Layanan pendidikan Bagi Anak Tunagrahita. Jurnal Santiaji Pendidikan, Vol. 9 No., 116-126. https://doi.org/https://doi.org/10.36733/jsp.v9i2.

Ningsih, S. Y., \& Mahyuddin, N. (2021). Desain E-Module Tematik Berbasis Kesantunan Berbahasa Anak Usia Dini di Taman Kanak-Kanak. Jurnal Obsesi : Jurnal Pendidikan Anak Usia Dini, 6(1), 137-149. https://doi.org/10.31004/obsesi.v6i1.1217.

Nugraha, M. F. (2017). Iklim Organisasi dan Kepuasan Kerja Guru di Sekolah Singosari Delitua. Jurnal Diversita Available, 3(1), 67-74. https://doi.org/10.31289/diversita.v5i1.2402.

Nursyahidah, F., Putri, R. I. I., \& Somakim. (2013). Supporting First Grade Students' Understanding of Addition Up to 20 Using Traditional Game. Journal on Mathematics Education, 4(2), 212-223. https://doi.org/10.22342/jme.4.2.557.212-223.

Priyadarshee Patra, Jyoti Prakash, B. P. (2016). Stress and Coping in Parents of Children with Mental Retardation. Delhi Psychiatry Journal, Vol. 19 No(1), 41-47.

Puspitasari, A. D. (2019). Penerapan Media Pembelajaran Fisika Menggunakan Modul Cetak dan Modul Elektronik pada Siswa SMA. Jurnal Pendidikan Fisika, 7(1), 17-25. https://doi.org/10.24252/jpf.v7i1.7155.

Putri Maysa \& Ummil khairiyah. (2019). Hardiness Dan Stres Pengsuhan Pada Ibu Dengan Anak Berkebutuhan Khusus. Jurnal Riset Aktual Psikologi Universitas Negeri Padang, Vol $\quad 10 \quad$ No., https://doi.org/https://doi.org/10.24036/rapun.v10i1.105017.

Rahmadani, A. F. R. \& A. (2019). Pengalaman Pengasuhan Single Mother Yang Memiliki Anak Disabilitas Intelektual (Studi Interpretative Phenomenological Analysis). Jurnal Empati, $8(1)$, https://ejournal3.undip.ac.id/index.php/empati/article/view/23589.

Sapriyah. (2019). Media Pembelajaran Dalam Proses Belajar Mengajar. Prosiding Seminar Nasional Pendidikan FKIP Universitas Sultan Agung Tirtayasa, 2(1), 470-477.

Sedana, I. M. S. \& I. N. (2020). Mempertahankan Eksistensi Media Cetak Di Tengah Gempuran Media Online. Jurnal Komunikasi Dan Budaya, 01, 56-64.

Silitonga, M. (2019). Hubungan Pola Asuh Orang Tua Dengan Agresifitas Anak Di SMPN 194 Jakarta Timur. Jurnal Kesejahteraan Keluarga Dan Pendidikan Universitas Negeri Jakarta, Vol 1 No.(April 2014). https://doi.org/10.21009/JKKP.011.02.

Siti Fatimah Mutia Sari, Binahayati, B. M. (2017). Pendidikan Bagi Anak Tuna Grahita (Studi Kasus Tunagrahita Sedang Di Slb N Purwakarta). Prosiding Penelitian Dan Pengabdian Kepada Masyarakat, 4(2), 217-222. https://doi.org/10.24198/jppm.v4i2.14273. 
Siti, N., \& Siregar, S. (2013). Persepsi Orang Tua terhadap Pentingnya Pendidikan bagi Anak. Jurnal IImu Pemerintahan Dan Sosial Politik UMA, 1(1), 11-27. https://doi.org/doi.org/10.31289/jppuma.v1i1.550.

Smith, P., Warrican, S. J., Kumi-Yeboah, A., \& Richards, J. (2018). Understanding AfroCaribbean educators' experiences with Englishes across Caribbean and U.S. contexts and classrooms: Recursivity, (re)positionality, bidirectionality. Teaching and Teacher Education, 69. https://doi.org/10.1016/j.tate.2017.10.009.

Subagyo, H. B. S. \&. (2017). Peningkatan Aktifitas Dan Hasil Belajar Dengan Metode Problem Basic Learning (PBL) Pada Mata Pelajaran Tune Up Motor Bensin Siswa Kelas XI Di SMK Insan Cendekia Turi Sleman Tahun Ajaran 2015/2016. Jurnal Taman Vokasi, 5(1), 40-45. https://doi.org/10.30738/jtv.v5i1.1428.

Sugiono. (2010). Metode Penelitian Pendidikan Pendekatan Kuantitatif, Kualitatif dan R\&D. Alfabeta.

Sutinah, \& Saswati, N. (2017). Psychoeducation Therapy Reduces Burden And Improves Family Ability In Caring For Mental Retardation Children. Indonesian Nursing Journal Of Education And Clinic (INJEC), Vol.2 No.(9), 85-104. https://doi.org/10.24990/injec.v2i1.126.

Tri Na'imah, Nur 'Aini, D. S. S. (2017). Orientasi Happiness Pada Orang Tua Yang Memiliki Anak Tunagrahita Ringan. Jurnal Psikologi Universitas Diponegoro, Vol 16 No(1), 32 39. https://doi.org/10.14710/jpu.16.1.32-39

Upendra, S., Sweta, \& Bhupendra, S. (2020). Intellectual Disability and its Association with Care Givers Burden at Sasaram. International Journal of Cognition and Behaviour, 3(1), 1-6. https://doi.org/10.23937/2690-3172/1710005.

Verma, A., Srivastava, P., \& Kumar, P. (2016). Stress among Parents having Children with Mental Retardation: A Gender Perspective. Jurnal of Disability Management and Rehabilitation, 2(1979), 68-72.

Westomi, J. A., Ibrahim, N., \& Sukardjo, M. (2018). Pengembangan Paket Modul Cetak Mata Pelajaran Pendidikan Agama Islam (PAI) untuk Siswa SMA Negeri 1 Wangi-wangi Kabupaten Wakatobi. JTP - Jurnal Teknologi Pendidikan, 20(2), 138-151. https://doi.org/10.21009/jtp.v20i2.8628.

Winarsih, S., Hendra, J., Idris, F. H., \& Adnan, E. (2013). Panduan penanganan nak berkebutuhan khusus bagi pendamping (orang tua, keluarga, dan masyarakat). In Kementerian Pemberdayaan Perempuan dan Perlindungan Anak Republik Indonesia.

Yonanda, D. A. (2017). Peningkatan Pemahaman Siswa Mata Pelajaran PKn Tentang Sistem Pemerintahan Melalui Metode M2M (Mind Mapping) Kelas IV MI Mambaul Ulum Tegalgondo Karangploso Malang. Jurnal Cakrawala Pendas, 3(1), 53-63. https://doi.org/http://dx.doi.org/10.31949/jcp.v3i1.410. 